\title{
Isolation, identification, and pathological effects of beach sand bacterial extract on human skin keratinocytes in vitro
}

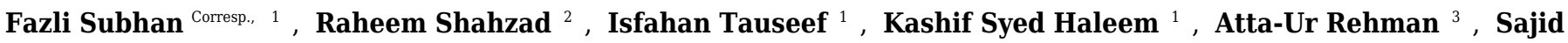 \\ Mahmood $^{3}$, In-Jung Lee ${ }^{\text {Corresp. } 2}$ \\ ${ }^{1}$ Department of Microbiology, Hazara University, Mansehra, Pakistan \\ 2 School of Applied Biosciences, Kyungpook National University, Daegu, South Korea \\ 3 Department of Zoology, Hazara University, Mansehra, Pakistan \\ Corresponding Authors: Fazli Subhan, In-Jung Lee \\ Email address: fazlisubhan93@gmail.com, ijlee@knu.ac.kr
}

Background. Beaches are recreational spots for people. However, beach sand contains harmful microbes that affect human health, and there are no established methods for either sampling and identifying beach-borne pathogens or managing the quality of beach sand.

Method. This study was conducted with the aim of improving human safety at beaches and augmenting the quality of the beach experience. Beach sand was used as a resource to isolate bacteria due to its distinctive features and the biodiversity of the beach sand biota. A selected bacterial isolate termed FSRS was identified as Pseudomonas stutzeri using 16S rRNA sequencing and phylogenetic analysis, and the sequence was deposited in the NCBI GenBank database under the accession number MF599548. The isolated $P$. stutzeri bacterium was cultured in Luria-Bertani growth medium, and a crude extract was prepared using ethyl acetate to examine the potential pathogenic effect of $P$. stutzeri on human skin. A human skin keratinocyte cell line (HaCaT) was used to assess cell adhesion, cell viability, and cell proliferation using a morphological analysis and a WST-1 assay.

Result. The crude $P$. stutzeri extract inhibited cell adhesion and decreased cell viability in HaCaT cells. We concluded that the crude extract of $P$. stutzeri FSRS had a strong pathological effect on human skin cells.

Discussion. Beach visitors frequently get skin infections, but the exact cause of the infections is yet to be determined. The beach sand bacterium $P$. stutzeri may, therefore, be responsible for some of the dermatological problems experienced by people visiting the beach. 
1 Isolation, Identification, and Pathological Effects of Beach Sand

3 Fazli Subhan $^{\text {a\#\# }}$, Raheem Shahzad ${ }^{\text {b\# }}$, Isfahan Tauseef ${ }^{\mathrm{a}}$, Kashif Syed Haleem ${ }^{\mathrm{a}}$, Atta Ur-rehman ${ }^{\mathrm{d}}$,

4 Sajid Mahmood ${ }^{\mathrm{d}}$, and In-Jung Lee (c, $^{\mathrm{b} *}$

5 a Department of Microbiology, Hazara University, Mansehra, 21300, Pakistan

6 bschool of Applied Biosciences, Kyungpook National University, Daegu 41566, Republic of

7 Korea

$8{ }^{\mathrm{c}}$ Research Institute for Dok-do and Ulleung-do Island, Kyungpook National University,

9 Daegu 41566, Republic of Korea

10 Department of Zoology, Hazara University, Mansehra, 21300, Pakistan

11 *Correspondence: In-Jung Lee, School of Applied Biosciences, Kyungpook National University,

12 Daegu 41566, Republic of Korea

13 Email: ijlee@knu.ac.kr

14 "Fazli Subhan and Raheem Shahzad contributed equally as first authors 


\section{Abstract}

16 Background. Beaches are recreational spots for people. However, beach sand contains harmful

17 microbes that affect human health, and there are no established methods for either sampling and

18 identifying beach-borne pathogens or managing the quality of beach sand.

19 Method. This study was conducted with the aim of improving human safety at beaches and 20 augmenting the quality of the beach experience. Beach sand was used as a resource to isolate

21 bacteria due to its distinctive features and the biodiversity of the beach sand biota. A selected

22 bacterial isolate termed FSRS was identified as Pseudomonas stutzeri using 16S rRNA

23 sequencing and phylogenetic analysis, and the sequence was deposited in the NCBI GenBank

24 database under the accession number MF599548. The isolated P. stutzeri bacterium was cultured

25 in Luria-Bertani growth medium, and a crude extract was prepared using ethyl acetate to

26 examine the potential pathogenic effect of $P$. stutzeri on human skin. A human skin keratinocyte

27 cell line $(\mathrm{HaCaT})$ was used to assess cell adhesion, cell viability, and cell proliferation using a

28 morphological analysis and a WST-1 assay.

29 Result. The crude P. stutzeri extract inhibited cell adhesion and decreased cell viability in HaCaT

30 cells. We concluded that the crude extract of $P$. stutzeri FSRS had a strong pathological effect on

31 human skin cells.

32 Discussion. Beach visitors frequently get skin infections, but the exact cause of the infections is

33 yet to be determined. The beach sand bacterium P. stutzeri may, therefore, be responsible for

34 some of the dermatological problems experienced by people visiting the beach. 
36 Beaches are recreational sites where numerous leisure activities can be carried out, including

37 sunbathing and various sports and games. Therefore, beaches are economically important, and the

38 care and maintenance of the coastal environment is important in many countries (Halliday and

39 Gast, 2011).

40 Unfortunately, there have been several negative reports regarding the condition of beaches and

41 the incidence of diseases acquired by visitors. For example, Heaney and colleagues reported that

42 visitors to both freshwater and marine beaches in different parts of the USA in 2003-2005 had an

43 increased chance of contracting diarrhea, vomiting, and nausea. Staphylococcus saprophyticus is

44 a causative agent of skin and urinary tract infections in young women, and this bacterium was

45 reported to be present at a Brazilian beach (De Sousa et al., 2017). There have been several other

46 reports of similar issues, including reports by the Environmental Protection Agency and the

47 Centers for Disease Control and Prevention (Spivey, 2009) and a recent paper (He et al., 2017).

48 The skin is the largest organ in the body and provides a primary barrier against various infectious

49 agents. Because the skin is constantly in direct contact with the external environment, it harbors

50 multiple types of microbes. Some of those microbes are potentially pathogenic and could lead to

51 serious infections under certain conditions (Soufi and Soufi, 2016). The most common pathogenic

52 bacteria in the seaside environment belong to the genera Staphylococcus and Streptococcus (Lee

53 et al., 2016). Similarly, the most common bacteria that colonize the skin are usually gram-

54 positive species, including Staphylococcus epidermidis, Corynebacterium species,

55 Staphylococcus aureus, and Streptococcus pyogenes (Todar, 2008, Braun et al., 2015). Human

56 skin is one of the most significant targets for the pathogenic bacteria present at beaches. In this

57 regard, it has been reported that about $24 \%$ of the UK civilian population experiences a 
58 pathological skin condition each year. In 2009-2010, about 900,000 patients were referred to

59 dermatologists in England (Tanzer et al., 2014).

60 A healthy and functioning skin barrier provides protection against dehydration, the penetration of

61 various microorganisms, allergens, chemical irritants, reactive oxygen species, and radiation.

62 Human keratinocytes are the key cells in the skin barrier that provide the skin's protective

63 function (Salmon et al., 1994). The skin has several physical defense mechanisms that allow it to

64 protect the body against pathogenic microbial infections, including a low $\mathrm{pH}$ and the secretion of

65 sebaceous fluid and fatty acids, which act together to inhibit pathogen growth. In addition, the

66 skin possesses its own normal protective flora (McAdam and Sharp, 2005).

67 Certain less common bacterial skin infections, such as those by Vibrio vulnificus, are acquired in

68 hospitals or nursing homes, and after swimming in a pond, lake, or ocean. Vibrio vulnificus is a

69 pathogenic gram-negative bacterium that is motile, curved, and rod-shaped (Jones et al., 2009).

70 V. vulnificus infections have been reported in swimmers with open wounds, and they can cause

71 ulceration of the skin (Harseman and Surani, 2011). The increase in the frequency of beach-visits

72 by people has led to an increased incidence of bacterial infections. Therefore, this topic needs to

73 be explored to improve the safety of humans visiting beaches.

74 Pseudomonas stutzeri is a gram-negative, aerobic, non-fermenting, and oxidase-positive

75 bacterium. P. stutzeri is most commonly isolated patient samples in hospitals (e.g., from surgical

76 wounds, blood, the respiratory tract, and urine) (Holmes, 2004; Taneja et al., 2004). The

77 prevalence of $P$. stutzeri in settings other than hospitals has not been explored. This study aimed

78 to confirm the presence of $P$. stutzeri in beach sand and then examine the effects of a P. stutzeri

79 extract on the cell adhesion and cell viability of a human skin keratinocyte to understand whether

80 P. stutzeri presents a potential pathological threat to beach-goers.

\section{METHODS}




\section{Sample Collection and Isolation of Bacterial Strains}

83 Sand samples were collected from the beaches in Busan, Republic of Korea. The contaminating

84 plant debris were removed. Each sample (10 g) was transferred to an autoclaved flask that

85 contained sterile Amies solution (Amies, 1967). The resulting suspension was serially diluted (10-

$\left.86^{4}\right)$ and $0.1 \mathrm{~mL}$ of the diluted suspension was plated onto Luria-Bertani (LB) agar medium (10 g

87 tryptone, $5 \mathrm{~g}$ yeast extract, and $10 \mathrm{~g} \mathrm{NaCl}, \mathrm{pH} 7.0 \pm 0.2$, autoclaved for $15 \mathrm{~min}$ at $121^{\circ} \mathrm{C}$ ) and

88 incubated at $28^{\circ} \mathrm{C}$ for $48 \mathrm{~h}$ (Kang et al., 2015). The plates were inspected daily. Colonies were

89 distinguished based on their morphology and subsequently streaked onto fresh plates.

\section{Identification and Phylogenetic Analysis}

91 The taxonomic identification of the selected bacterial isolate, Fazli Subhan Raheem Shahzad

92 (FSRS), was performed based on sequencing its 16S rRNA gene using the $27 \mathrm{f}$ and $1492 \mathrm{r}$ primers

93 and BLASTing the FSRS 16S rRNA sequence against the NCBI GenBank database, as described

94 by Shahzad et al. (2016). Closely related sequences with the highest homology (i.e., the lowest E

95 values) were selected and aligned by ClustalW using the MEGA version 7.0 software.

\section{Preparation of a Crude Bacterial Extract}

97 An ethyl acetate extract of the FSRS bacterial isolate was prepared by culturing FSRS in LB

98 broth for 7 days at $28^{\circ} \mathrm{C}$ and $120 \mathrm{rpm}$ in a shaking incubator. After 7 days, the culture broth was

99 centrifuged at $10,000 \times g$, and cell-free LB broth was adjusted to $\mathrm{pH} 2.5$ and then completely

100 extracted with an equal volume of ethyl acetate three times. The extracted ethyl acetate was then

101 completely dried using a rotary evaporator to obtain a crude solid bacterial ethyl acetate extract,

102 which was then re-dissolved in sterilized RNase-free water and used for further study. 
103 Preparation of a Working Solution of the Crude Bacterial Extract

104 A $5 \mathrm{mg} / \mathrm{mL}$ stock solution of the crude extract was prepared using distilled water as the solvent.

105 The solution was filter-sterilized and a working solution of $1 \mathrm{mg} / \mathrm{mL}$ was prepared for the final

106 treatments at doses of 100,300 , and $500 \mathrm{ng} / \mathrm{mL}$.

\section{Cell Culture}

108 HaCaT keratinocytes were purchased from the Cell Line Service of the German Cancer Research

109 Center (Heidelberg, Germany) and maintained in Dulbecco's modified Eagle medium (Life

110 Technologies, Carlsbad, CA, USA) supplemented with 10\% fetal bovine serum (Life

111 Technologies), $100 \mathrm{U} / \mathrm{mL}$ penicillin, and $100 \mathrm{mg} / \mathrm{mL}$ streptomycin (Life Technologies) at $37^{\circ} \mathrm{C}$ in

112 a humidified atmosphere containing $5 \% \mathrm{CO}_{2}$.

\section{HaCaT Cell Adhesion}

$114 \mathrm{HaCaT}$ cells were seeded into six-well plates at a density of $2 \times 10^{5}$ cells/well in $3 \mathrm{~mL}$ of

115 medium. The cells were treated with varying concentrations $(0,100,300$, and $500 \mathrm{ng} / \mathrm{mL})$ of

116 crude bacterial extract for 24 and $48 \mathrm{~h}$ in serum-free medium. Morphological changes of the

117 HaCaT cells were observed and images were captured under an inverted light microscope (Nikon

118 Corporation, Tokyo, Japan) after 24 and $48 \mathrm{~h}$. The same area of cells was noted and captured at

119 each time point. The images were captured at $200 \times$ magnification and the scale bar represents 50 $120 \mu \mathrm{m}$.

\section{HaCaT Cell Viability}


$122 \mathrm{HaCaT}$ cells were plated in flat-bottomed, 96-well, microtiter plates at $1 \times 10^{4}$ cells/well and

123 cultured for $24 \mathrm{~h}$. After starvation in serum-free media for $24 \mathrm{~h}$, the cells were treated with the

124 crude bacterial extract for a further 24 or $48 \mathrm{~h}$. Cell proliferation was determined after treatment

125 using a colorimetric water-soluble tetrazolium salt-1 (WST-1) cell proliferation assay (EZ-Cytox

126 assay kit, Daeil Lab Service, Seoul, Korea). Metabolically active cells generate a colored dye

127 through the action of a cellular dehydrogenase on WST-1, which can be measured using a

128 microplate reader (Tecan, Männedorf, Switzerland) at $450 \mathrm{~nm}$ according to the manufacturer's

129 instructions. The IC50 value were calculated as presented here is given as percent inhibition by

130 the drug. The IC50 were calculated using Curve-Fit Model through Table curve Software and the

131 following formula was used.

132 The value were subtracted from 100 as total cells-viable cells= percent inhibited cells

\section{Statistical Analysis}

134 The data are expressed as mean \pm standard deviation. The results were statistically analyzed by a

135 two-tailed Student's $t$-test. Statistically, differences were considered to be significant at $p<0.05$. 


\section{RESULTS}

\section{Isolation and identification}

138 To gain insight into the genome sequence diversity of P. stutzeri populations, various isolates of

139 P. stutzeri were selected from beach sands in South Korea (Busan) and several other geographical

140 locations (Fig. 1). Among the isolated strains, the FSRS strain was selected. The 16S rRNA

141 sequence of FSRS was compared to other 16S rRNA sequences in the NCBI database

142 (http://www.ncbi.nlm.nih.gov/) using a BLAST search to identify its closest neighbors. The

143 results showed that FSRS was closely related to members of the genus Pseudomonas and shared

144 the highest sequence identity (100\%) with P. stutzeri (KF894696).

145 A phylogenetic or evolutionary tree is a branching diagram that represents the inferred

146 evolutionary relationships among various biological species based upon similarities and

147 differences in their physical or genetic characteristics. A phylogenetic analysis based on $16 \mathrm{~S}$

148 rRNA sequences showed that FSRS is closely related to other P. stutzeri strains, as shown in Fig.

149 2. A phylogenetic tree was constructed by the neighbor-joining method using CLUSTAL-X 1.8

150 software (Sasson et al., 2017). Based on this analysis, FSRS was formally identified as P. stutzeri,

151 and its 16S rRNA gene sequence was deposited in the NCBI GenBank database under accession

152 number MF599548.

\section{HaCaT cell adhesion}

154 The effect of FSRS on the adhesion of human skin keratinocytes was determined using HaCaT

155 cells. HaCaT cells were seeded in a six-well plate, treated with different amounts of crude FSRS

156 extract for 24 or $48 \mathrm{~h}$, and then examined by phase contrast microscopy. The results showed that

157 the crude FSRS extract inhibited HaCaT cell adhesion in both a dose- and time-dependent 
158 manner, as shown in Fig. 3.

\section{HaCaT cell viability}

160 We determined the effect of the FSRS extract on HaCaT cell viability using a WST-1 assay

161 (Subhan et al., 2017). HaCaT cells were cultured in a 96-well plate and then starved for $24 \mathrm{~h}$

162 before treatment with the FSRS crude extract. As shown in Fig. 4, the crude FSRS extract

163 significantly decreased the viability of HaCaT cells in both a dose- and time-dependent manner.

164 The IC50 value were calculated, which are $198.58 \mathrm{ng} / \mathrm{mL}$ for $24 \mathrm{hr}$ treatment and $97.61 \mathrm{ng} / \mathrm{mL}$

165 for $48 \mathrm{hr}$ treatment.

\section{DISCUSSION}

168 P. stutzeri was first named by Burri and Stutzer (1895), and later by van Niel and Allen (1952),

169 while it was phenotypically described by Lehmann and Neumann (1896). P. stutzeri has

170 previously been identified in contaminated and non-contaminated soils, marsh sediment, and

171 marine water (Sikorski et al., 2005; Lidbury et al., 2016). P. stutzeri is generally considered to be

172 a contaminant that can also be pathogenic to humans if their immunity is compromised. To our

173 knowledge, this is the first study to reveal the existence of pathogenic P. stutzeri in the sand from

174 a beach in Busan, South Korea, and furthermore demonstrate the pathological effects of an

175 extract of P. stutzeri on human skin.

176 We cultured beach-sand isolates and used the restriction fragment length polymorphism method

177 to identify their $16 \mathrm{~S}$ rRNA genes. This method has previously been described as being useful for

178 the characterization of bacterial isolates (Adderson et el., 2008). Through that analysis, the isolate

179 was confirmed to belong to the genus Pseudomonas and the species P. stutzeri (Bennasar et al., 
180

181

182

183

184

185

186

187

188

189

190

191

192

193

194

195

196

197

198

199

200

201

202

203

1996; Zhang et al., 2014). The 16S rRNA sequence was subsequently submitted to NCBI

(KF894696). Several different strains of P. stutzeri have been isolated from different sources, including patient samples in hospitals (wound pus, blood, urine, tracheal aspirates, and sputum), and they are often considered to be pathogenic (Tan et al., 1997; Ergin and Mutlu, 1999;

Manfredi et al., 2000). Consistent with this, several other species of the genus Pseudomonas are also considered to be pathogenic, although some of them have applications in bioremediation (Reisler and Blumberg, 1999; Castaldo et al., 2017; Mukherjee et al., 2017).

Having a sufficient understanding of the human pathological microbiome is necessary for the development of successful therapeutic approaches for their cure. Hence, it is important to identify and analyze their possible pathological effects on different parts of the human body, such as skin. In the present study, we demonstrated the presence of P. stutzeri, a potential human pathogen, in sand obtained from a beach in Busan, South Korea.

A previous study has reported the pathogenic effects of P. stutzeri on skin (Puzenat et al., 2004); hence, we focused on examining the effects of P. stutzeri extracts on skin in the present study. We decided to examine the effect of an extract of $P$. stutzeri on skin keratinocytes because they serve as the first line of defense against foreign invaders in humans. The HaCaT cell line was chosen for this study because HaCaT cells have been widely used as a keratinocyte model cell line in numerous dermatopathological studies.

Skin continually interacts with the external environment. As a result, it is exposed to and colonized by both pathogenic and non-pathogenic bacterial strains. Most of the skin surfacecolonizing bacteria are gram-positive species including Staphylococcus aureus and Streptococcus pyogenes (Kanayama et al., 2016). The normal flora in the skin provides protection against various pathogenic microflora, but the exact mechanism of interaction between the pathogenic and normal microflora in the skin is not well understood (Grice and Segre, 2011). It is thought 
204 that the normal skin flora secretes a variety of antimicrobial substances that protect human skin

205 from pathogenic bacterial infections (Weinberg et al., 1998; Rippon et al., 2016).

206 In addition to hosting the normal human skin flora, human skin serves as the first line of defense

207 against pathogenic microbial infection by providing a physical barrier, a low $\mathrm{pH}$, sebaceous fluid,

208 and fatty acids, which together serve to inhibit the growth of pathogens (Peschel et al., 2001).

209 Unfortunately, several pathogenic microorganisms can bypass these defensive mechanisms and

210 penetrate the integument, leading to tissue damage and the induction of an inflammatory response

211 (Roesner et al., 2016). Cellulitis is a common bacterial infection of the skin that is caused by

212 Staphylococcus or Streptococcus spp. that are commonly present on the skin (Swartz, 2004,

213 Stevens et al., 2014). Similarly, Pseudomonas spp. can also cause an infection when there is a

214 break in the skin (Nakagami et al., 2011). Currently, it is not understood how bacteria found in

215 beach sand can cause skin infections such as cellulitis. Through this study, we make a new

216 proposal that FSRS in beach sand may cause skin infections by inhibiting keratinocyte adhesion

217 and reducing keratinocyte viability, although further detailed studies are required to fully

218 understand the mechanism of action.

\section{CONCLUSIONS}

220 In conclusion, the present work demonstrated that bacterial isolates from beach sand collected

221 from Busan in South Korea contain FSRS, and their identification was based on 16S rRNA

222 sequencing data. An extract prepared from beach sand FSRS significantly inhibited the growth of

223 a human skin keratinocyte cell line by inhibiting cell adhesion and decreasing cell viability (Fig.

224 5). The extract from FSRS is one of the most potent microbial extracts tested against a human

225 skin keratinocyte cell line. Therefore, this study could be useful for understanding the pathology

226 of skin infections acquired at the beach. 
227

228

229

230

231

232

233

234

235

236

237

238

239

240

241

242

243

244

245

\section{REFERENCES}

Adderson EE, Boudreaux JW, Cummings JR, Pounds S, Wilson DA, Procop GW. 2008.

Hayden RT. Identification of clinical coryneform bacterial isolates: comparison of biochemical methods and sequence analysis of $16 \mathrm{~S}$ rRNA and rpoB genes. $J$ Clin Microbiol 46: 921-927.

Amies CR. 1967. A modified formula for the preparation of Stuart's transport medium. Can J Public Health 58: 296-300

Bennasar A, Rosselló-Mora R, Lalucat J, Moore ER. 1996. 16S rRNA gene sequence analysis relative to genomovars of Pseudomonas stutzeri and proposal of Pseudomonas balearica sp. nov. Int J Syst Bacteriol 46: 200-205.

Braun V, Eskens U, Hartmann A, Lang B, Kramer M, Schmidt MJ. 2015. Focal bacterial meningitis following ascending bite wound infection leading to paraparesis in a captive California sea lion (Zalophus californianus). J Zoo Wildl Med 46: 135-40.

Burri R, Stutzer A. 1895. Ueber Nitrat zersto“rende Bakterien und den durch dieselben bedingten Stickstoffverlust. Zentbl. Bakteriol. Parasitenkd. Abt II 1: 257-265.

Castaldo N, Givone F, Peghin M, Righi E, Sartor A, Bassetti M. 2017. Multidrug-resistant Pseudomonas aeruginosa skin and soft-tissue infection successfully treated with ceftolozane/tazobactam. J Glob Antimicrob Resist 9: 100-102.

de Sousa VS, da-Silva APS, Sorenson L, Paschoal RP, Rabello RF, Campana EH, Pinheiro 

Humans, Food, and Recreational Waters in Rio de Janeiro, Brazil. Int J Microbiol 2017: 4287547. species. East. J. Med 4: 65-69.

Ergin C, Mutlu G. 1999. Clinical distribution and antibiotic resistance of Pseudomonas

Grice EA, Segre JA. 2011. The skin microbiome. Nat Rev Microbiol 9: 244-253.

Halliday E, Gast RJ. 2011. Bacteria in beach sands: an emerging challenge in protecting Fish Scale Collagen Peptides Protect against CoC12/TNF- $\alpha$-Induced Cytotoxicity and Inflammation via Inhibition of ROS, MAPK, and NF- $\kappa$ B Pathways in HaCaT Cells. Oxidative Medicine and Cellular Longevity 17: 2017.

\section{Subhan F, Kang H, Lim Y, Ikram M, Baek SY, Jin S, Jeong YH, Kwak JY, Yoon S. 2017.} coastal water quality and bather health. Environ Sci Technol 45: 370-379.

He LS, Zhang PW, Huang JM, Zhu FC, Danchin A, Wang Y. 2017. The enigmatic genome of an obligate ancient Spiroplasma symbiont in a hadal holothurian. Appl Environ Microbiol AEM.01965-17.

Holmes B. 1986. Identification and distribution of Pseudomonas stutzeri in clinical material. $J$ Appl Bacteriol 60: 401-411. 
268

\section{Kanayama S, Ikeda F, Okamoto K, Nakajima A, Matsumoto T, Ishii R, Amano A,} Matsuzaki K, Matsumoto S. 2016. In vitro antimicrobial activity of ozenoxacin against methicillin-susceptible Staphylococcus aureus, methicillin-resistant S. aureus and Streptococcus pyogenes isolated from clinical cutaneous specimens in Japan. J Infect Chemother 22: 720-723.

\section{Kang SM, Khan AL, Waqas M, You YH, Hamayun M, Joo GJ, Shahzad R, Choi KS, Lee} IJ. 2015. Gibberellin-producing Serratia nematodiphila PEJ1011 ameliorates low temperature stress in Capsicum annuum L. Eur J Soil Biol 68: 85-93

Lee CS, Kim M, Lee C, Yu Z, Lee J. 2016. The Microbiota of Recreational Freshwaters and the Implications for Environmental and Public Health. Front Microbiol 7: 1826.

Lehman KB, Neumann. 1896. Atlas und Grundriss der Bakteriologie und Lehrbuch der speziellen bakteriologischen Diagnostik, $1^{\text {st }}$ (1896), 2nd (1899), 3rd (1904), 5th (1912), 6th (1920), and 7th (1927) ed. J. F. Lehman, München, Germany.

\section{Lidbury ID, Murphy AR, Scanlan DJ, Bending GD, Jones AM, Moore JD, Goodall A,} Hammond JP, Wellington EM. 2016. Comparative genomic, proteomic and exoproteomic analyses of three Pseudomonas strains reveals novel insights into the phosphorus scavenging capabilities of soil bacteria. Environ Microbiol 18: 3535-3549.

Manfredi R, Nanetti A, Ferri M, Chiodo F. 2000. Pseudomonas spp. complications in patients with HIV disease: an eight-year clinical and microbiological survey. Eur. $J$. Epidemiol 16: 111-118 
288 McAdam AJ. 2005. Sharpe AH. Infectious diseases - bacterial infections. In: Kumar V, Abbas

289

290

291

292

293

294

295

$$
\text { AK, Fausto N, editors. Robbins \& Cotran Pathologic Basis of Disease. Philadelphia: }
$$
Elsevier Inc, pp. 371-96.

Mukherjee AK, Bhagowati P, Biswa BB, Chanda A, Kalita BA. 2017. Comparative intracellular proteomic profiling of Pseudomonas aeruginosa strain ASP-53 grown on pyrene or glucose as sole source of carbon and identification of some key enzymes of pyrene biodegradation pathway. J Proteomics S1874-3919: 30263-30264.

\section{Nakagami G, Morohoshi T, Ikeda T, Ohta Y, Sagara H, Huang L, Sanada H. 2011.}

Contribution of quorum sensing to the virulence of Pseudomonas aeruginosa in pressure ulcer infection in rats. Wound Repair and Regeneration 19: 214-222.

\section{Peschel A, Jack RW, Otto M, Collins LV, Staubitz P, Nicholson G, Van Kessel KP. 2001.} Staphylococcus aureus resistance to human defensins and evasion of neutrophil killing via the novel virulence factor MprF is based on modification of membrane lipids with 1lysine. J. of Exp Med 193: 1067-1076.

Puzenat E, Chirouze C, Khayat N, Aubin F, Estavoyer JM, Humbert P, Hoen B. 2004. Ecthyma gangrenosum caused by Pseudomonas stutzeri with bacteraemia and systemic vascularitis. Rev. Med. Interne 25: 315-318.

Reisler RB, Blumberg H. 1999. Community-acquired Pseudomonas stutzeri vertebral osteomyelitis in a previously healthy patient: case report and review. Clin Infect Dis 29: 667-669.

Rippon M, Colegrave M, Ousey K. 2016. Incontinence-associated dermatitis: reducing 
adverse events. British journal of nursing 25: 1016-1021.

310 Roesner LM, Werfel T, Heratizadeh A. 2016. The adaptive immune system in atopic dermatitis and implications on therapy. Expert review of clinical immuno 12: 787-796.

Salmon JK, Armstrong CA, Ansel JC. 1994. The skin as an immune organ. West J Med 160: 146-152.

Sasson G, Kruger Ben-Shabat S, Seroussi E, Doron-Faigenboim A, Shterzer N, Yaacoby Bacteria Are Phylogenetically Related and Correlated with the Cow's Capacity To Harvest Energy from Its Feed. MBio 8: e00703-00717.

Shahzad R, Waqas M, Khan AL, Asaf S, Khan MA, Kang SM, Yun BW, Lee IJ. 2016.

Sikorski J, Lalucat J, Wackernagel W. 2005. Genomovars 11 to 18 of Pseudomonas stutzeri, Seed-borne endophytic Bacillus amyloliquefaciens RWL-1 produces gibberellins and regulates endogenous phytohormones of Oryza sativa. Plant Physiol Biochem 106: 236243.

Soufi Y, Soufi B. 2016. Mass Spectrometry-Based Bacterial Proteomics: Focus on Perspect 117: A392. 

diagnosis and management of skin and soft tissue infections: 2014 update by the infectious diseases society of America. Clin Infect Dis 59: 147.

Swartz MN. 2004. Clinical practice. Cellulitis. N Engl J Med 2004: 350:904.

Tan RJS, Lim EW, Sakazaki R. 1977. Unusual cause of urinarytract infection by Pseudomonas stutzeri in Singapore. Jpn. J. Exp. Med 47: 311-313.

Taneja N, Meharwal SK, Sharma SK, Sharma M. 2004. Significance and characterisation of pseudomonads from urinary tract specimens. J Commun Dis 36: 27-34.

Tanzer J, Macdonald A, Schofield S. 2014. Infective skin conditions in an adult sea-going population. J R Nav Med Serv 100: 47-55. 2008)

Van Niel CB, Allen MB. 1952. A note on Pseudomonas stutzeri. J. Bacteriol 64: 413-422.

Weinberg A, Krisanaprakornkit S, Dale BA. 1998. Epithelial antimicrobial peptides: review and significance for oral applications. Crit. Rev. in Oral Biol. Med 9: 399-414. oil reservoirs. Microbiol open 3: 446-456. 
350 Fig. 1. The geographical location of a beach in Busan, Republic of Korea, which attracts

351 numerous visitors, from where sand samples were collected.

352 Fig. 2. Neighbor-joining phylogenetic tree derived from aligning the most similar 16S rRNA

353 sequences in related taxa for a phylogenetic analysis of the bacterial isolate (FSRS) by MEGA 7.

354 The scale bar indicates 0.02 substitutions per nucleotide position. Bootstrap values (\%) based on

3551000 replications are given at each branch point.

356 Fig. 3. Human skin keratinocyte number and adhesion as assessed by phase contrast microscopy 357 after $24 \mathrm{hr}(\mathrm{A})$ and $48 \mathrm{hr}$ treatment (B). The number of HaCaT cells was reduced and their cell 358 morphology was changed by the FSRS extract in both a dose- and time-dependent manner, as 359 compared to control cells.

360 Fig. 4. HaCaT cell viability as assessed using a WST-1 assay. HaCaT cell viability was 361 significantly inhibited by the FSRS crude extract in both a dose- and time-dependent manner, as 362 compared to control cells $(n=3, p<0.05)$. The IC50 value were calculated, which are 198.58 $363 \mathrm{ng} / \mathrm{mL}$ for $24 \mathrm{hr}(\mathrm{A})$ treatment and $97.61 \mathrm{ng} / \mathrm{mL}$ for $48 \mathrm{hr}(\mathrm{B})$ treatment.

364 Fig. 5. Schematic representation of beach sand sample collection from the collection site, and the 365 processing, identification, and effect of the FSRS crude extract on the adhesion and viability of $366 \mathrm{HaCaT}$ cells in vitro. 
Figure 1

The geographical location of a beach in Busan, Republic of Korea, which attracts numerous visitors, from where sand samples were collected.

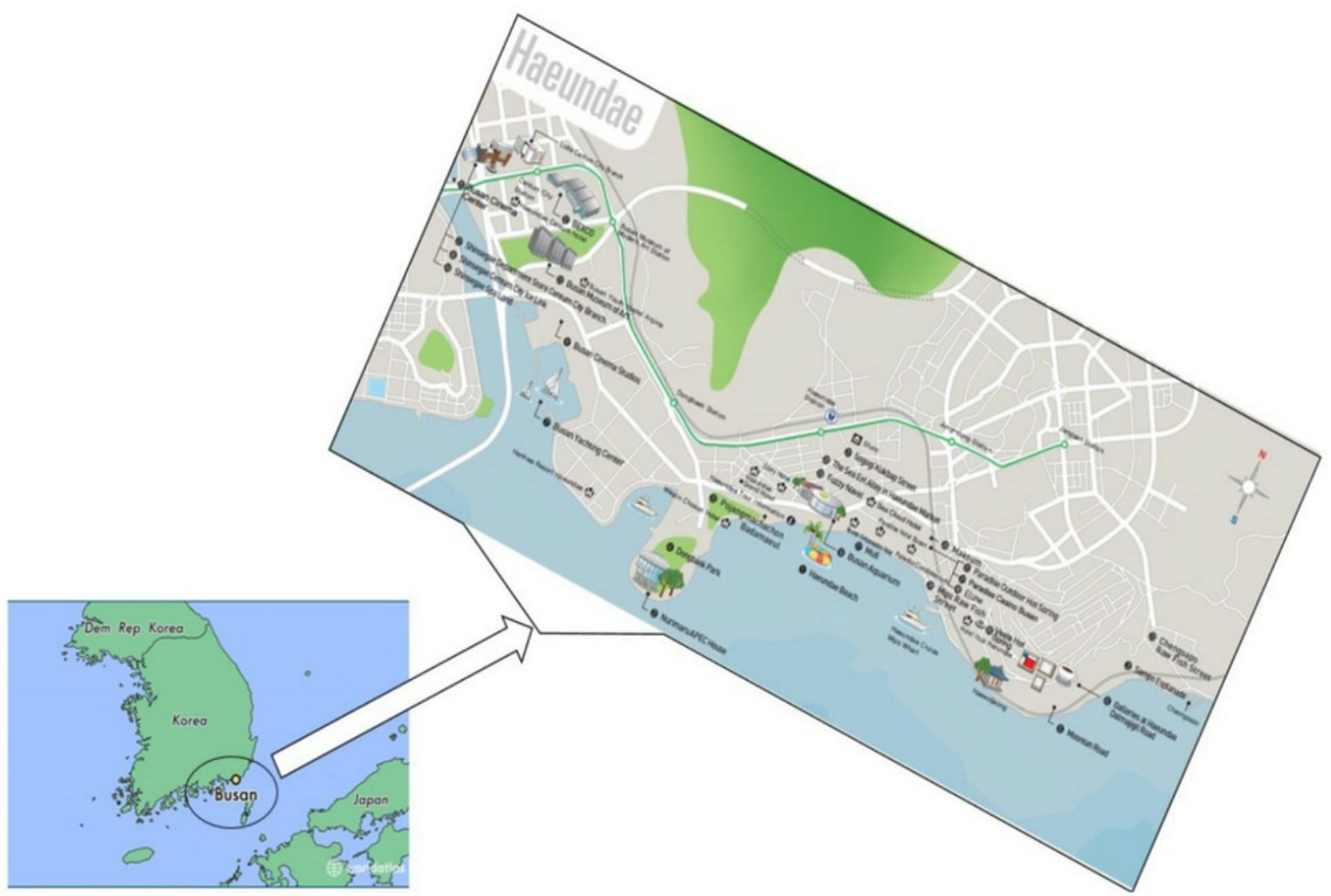


Figure 2

Figure 2

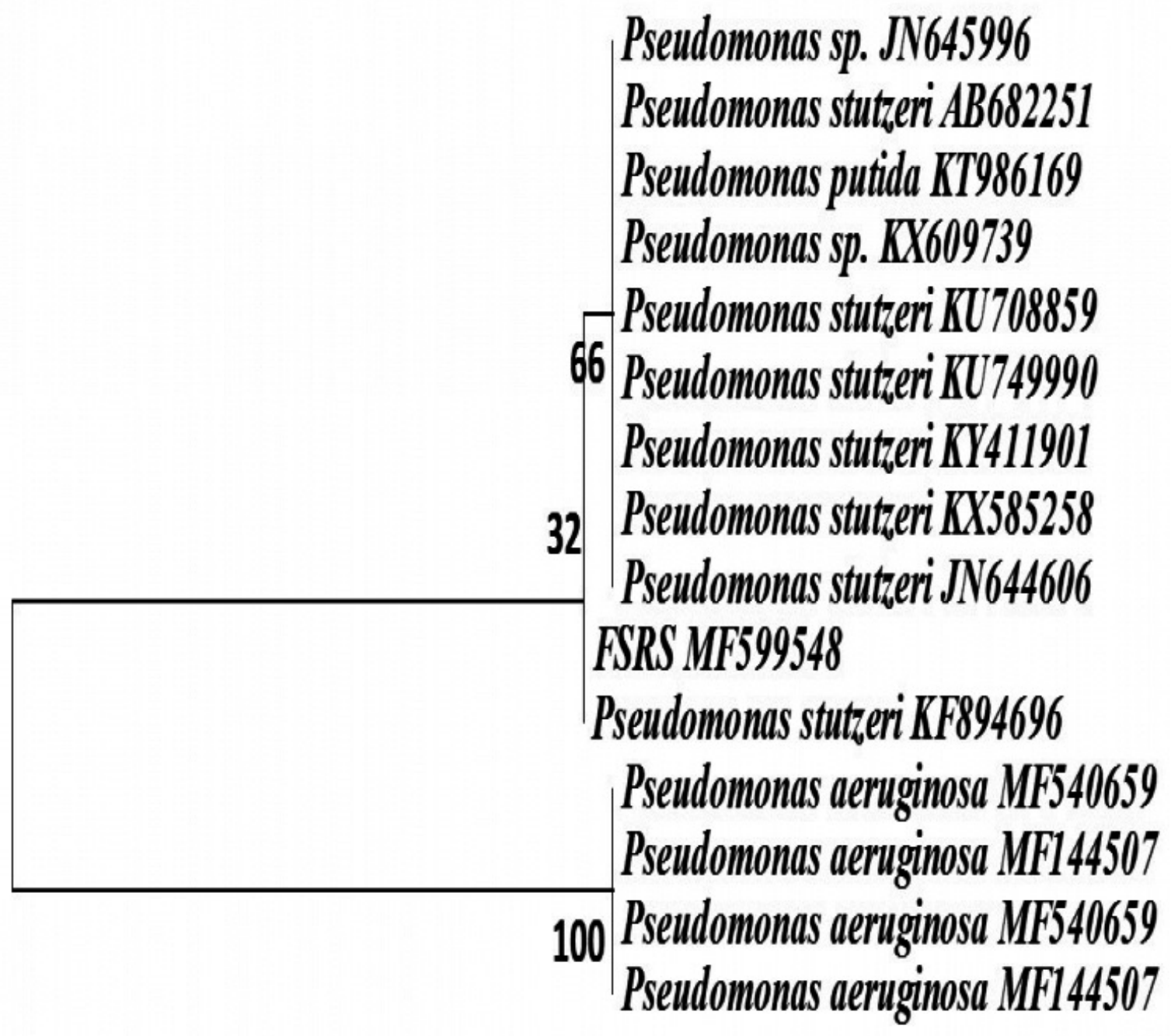

$\widehat{0.002}$ 
Figure 3

Figure 3

A

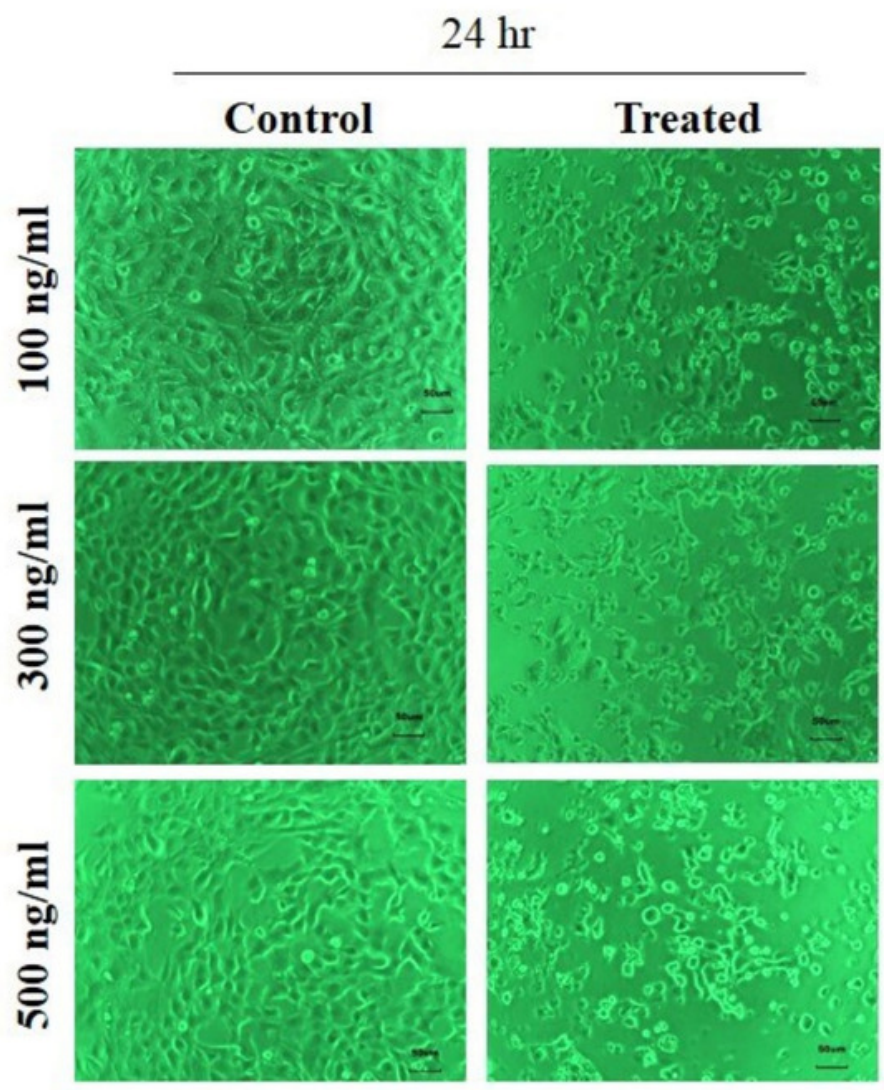

B

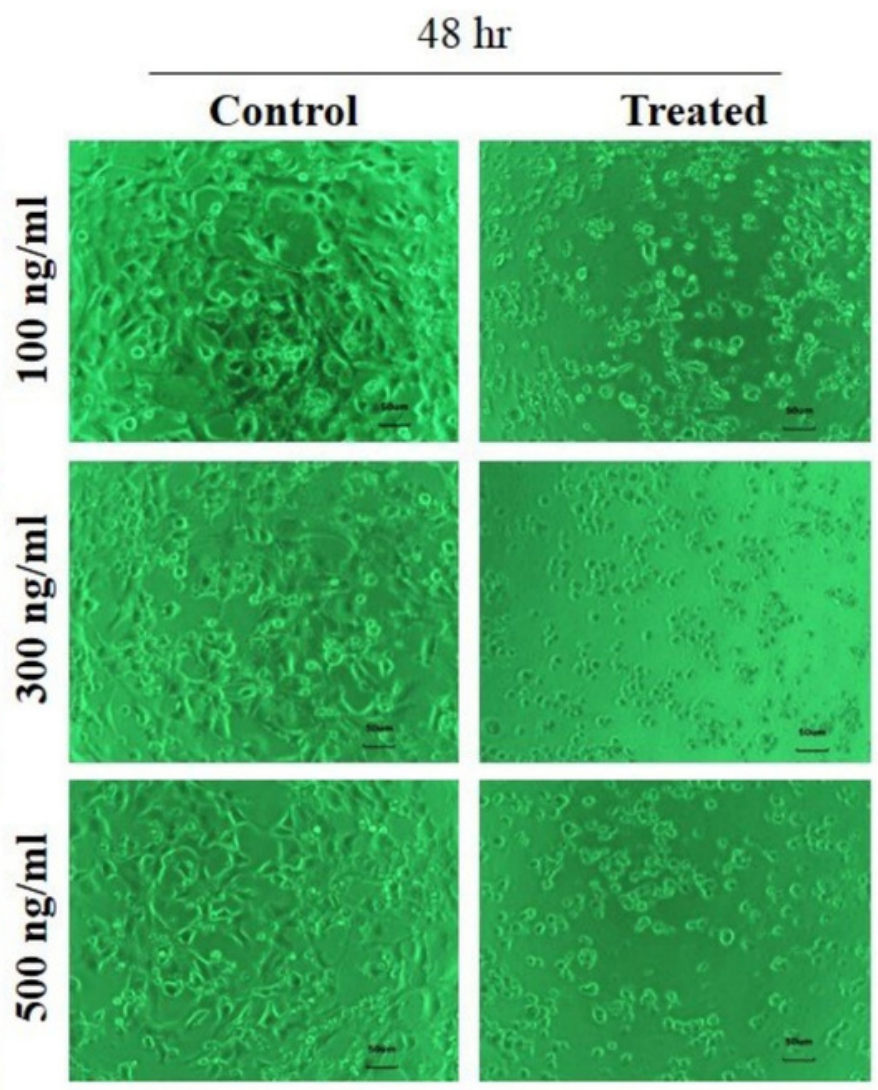




\section{Figure 4}

Figure 4

HaCaT cell viability as assessed using a WST-1 assay. HaCaT cell viability was significantly inhibited by the FSRS crude extract in both a dose- and time-dependent manner, as compared to control cells $(n=3, p<0.05)$. The IC50 value were calculated, which are $198.58 \mathrm{ng} / \mathrm{mL}$ for $24 \mathrm{hr}(\mathrm{A})$ treatment and $97.61 \mathrm{ng} / \mathrm{mL}$ for $48 \mathrm{hr}$ (B) treatment.

A

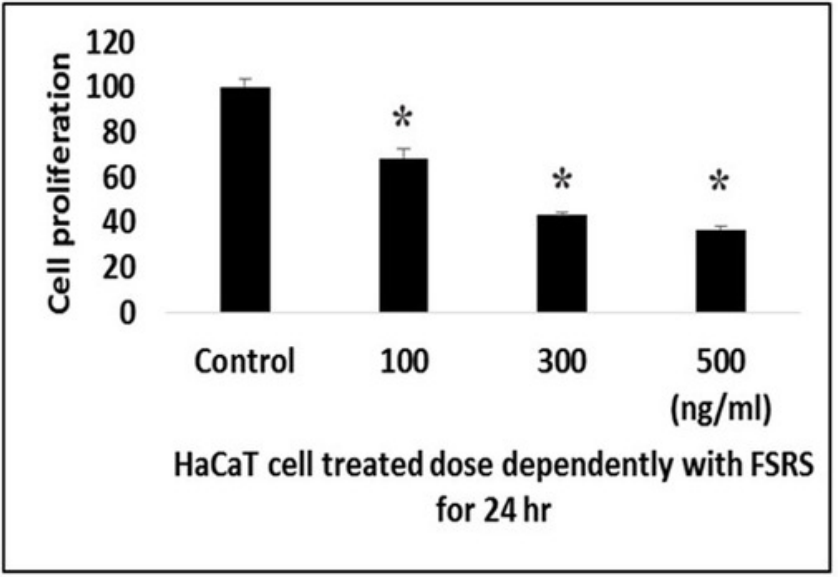

B

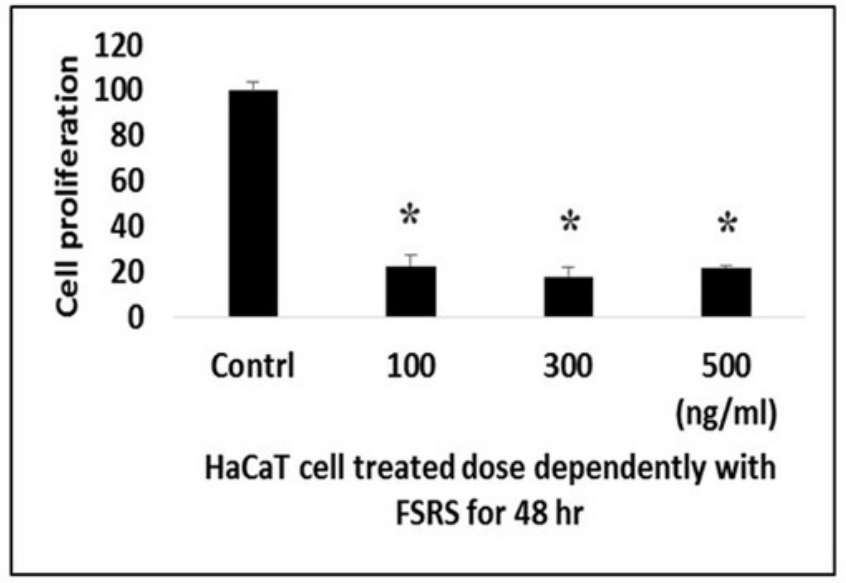


Figure 5

Figure 5

Schematic representation of beach sand sample collection from the collection site, and the processing, identification, and effect of the FSRS crude extract on the adhesion and viability of HaCaT cells in vitro.

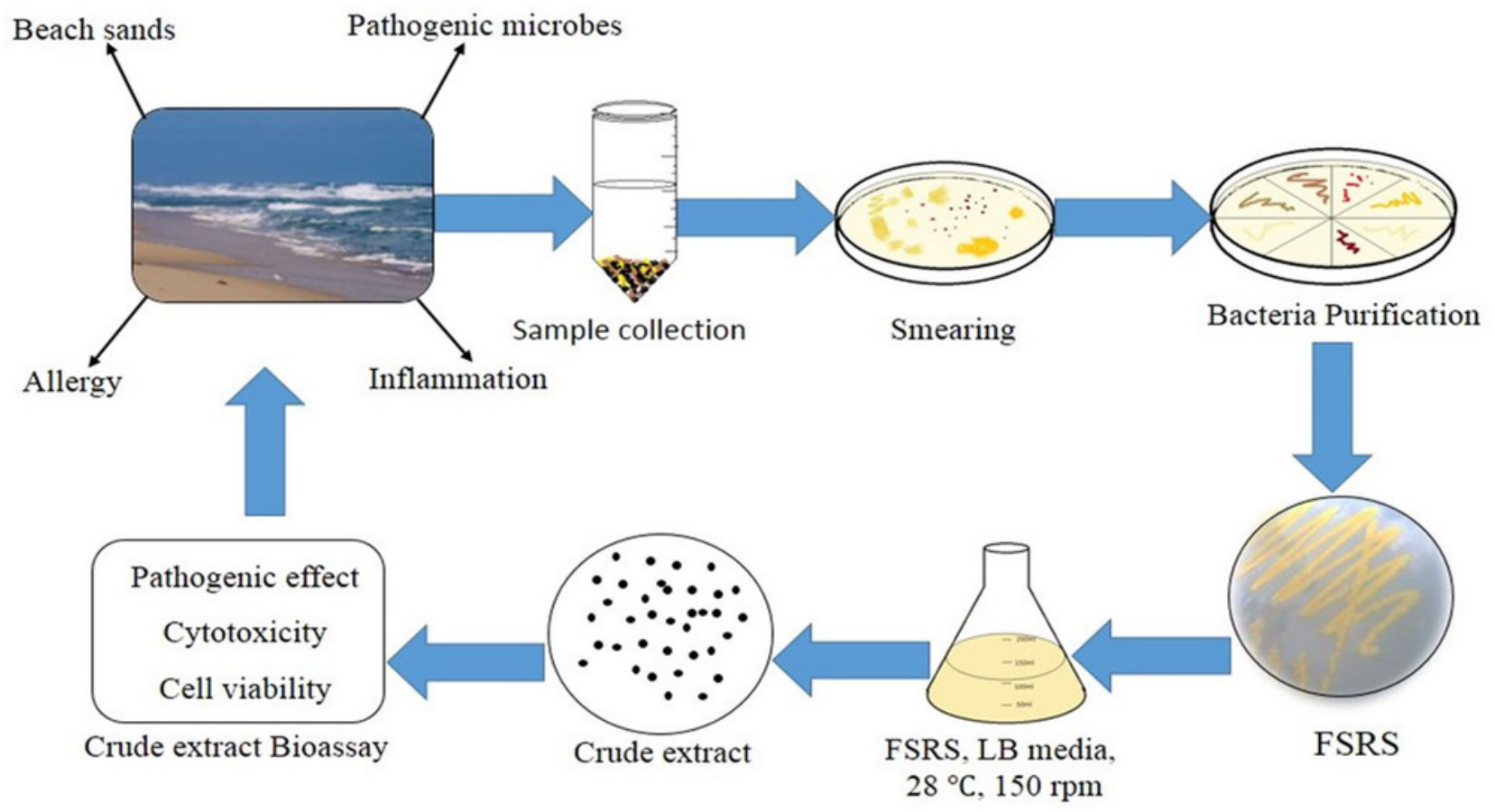

